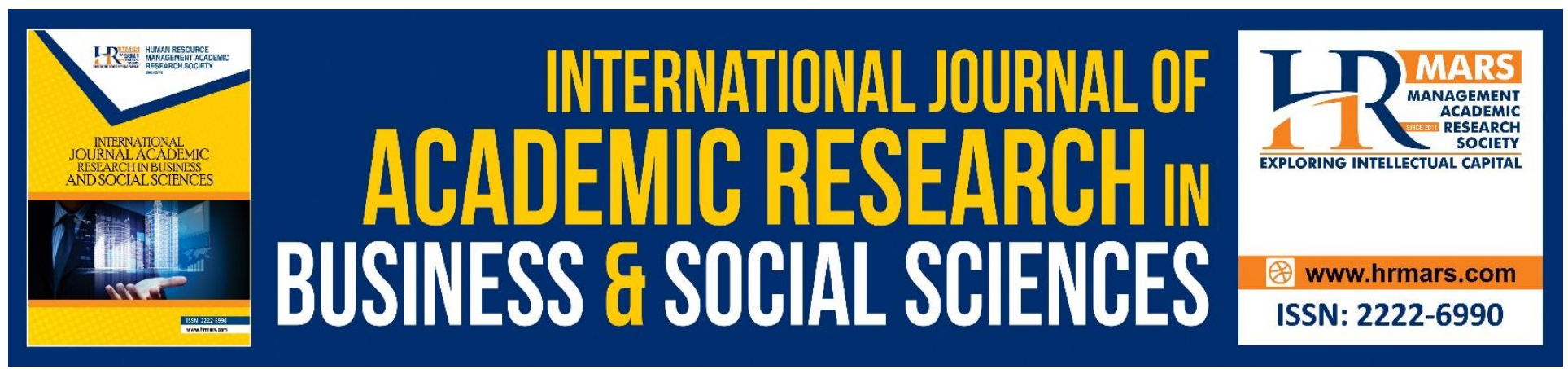

\title{
Fatwa as a Disseminator of Islamic Laws among Community of Malaysia
}

Wan Mohd Khairul Firdaus Wan Khairuldin, Wan Nur Izzati Wan Nor Anas,
Abdul Hanis Embong

To Link this Article: http://dx.doi.org/10.6007/IJARBSS/v8-i11/4925

DOI: $10.6007 /$ IJARBSS/v8-i11/4925

Received: 21 Oct 2018, Revised: 17 Nov 2018, Accepted: 04 Dec 2018

Published Online: 05 Dec 2018

In-Text Citation: (Khairuldin, Anas, \& Embong, 2018)

To Cite this Article: Khairuldin, W. M. K. F. W., Anas, W. N. I. W. N., \& Embong, A. H. (2018). Fatwa as a

Disseminator of Islamic Laws among Community of Malaysia. International Journal of Academic Research in Business and Social Sciences, 8(11), 516-521.

\section{Copyright: (C) 2018 The Author(s)}

Published by Human Resource Management Academic Research Society (www.hrmars.com)

This article is published under the Creative Commons Attribution (CC BY 4.0) license. Anyone may reproduce, distribute, translate and create derivative works of this article (for both commercial and non-commercial purposes), subject to full attribution to the original publication and authors. The full terms of this license may be seen

at: http://creativecommons.org/licences/by/4.0/legalcode

Vol. 8, No. 11, 2018, Pg. 516 - 521

http://hrmars.com/index.php/pages/detail/IJARBSS

JOURNAL HOMEPAGE

Full Terms \& Conditions of access and use can be found at http://hrmars.com/index.php/pages/detail/publication-ethics 


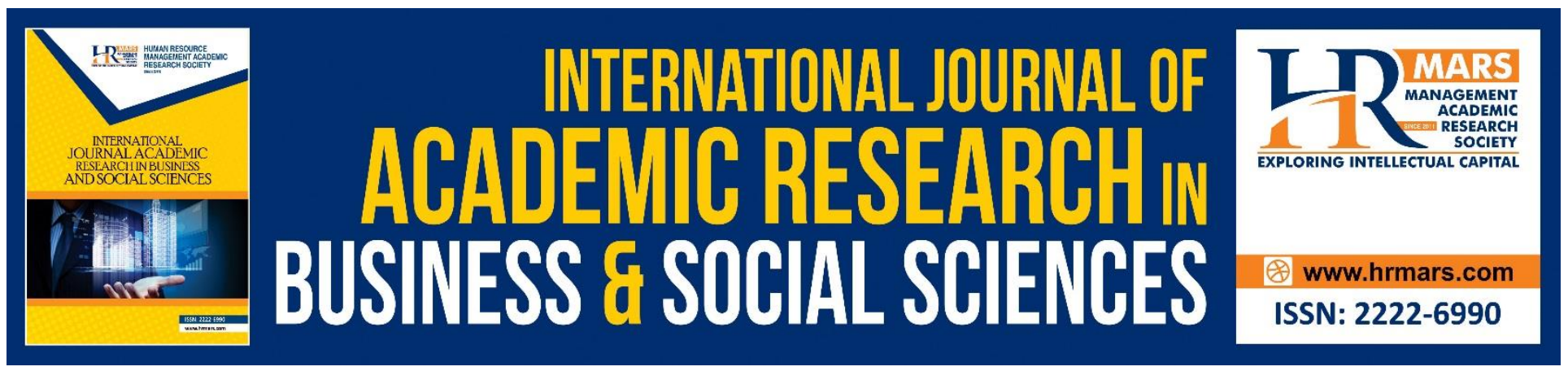

\title{
Fatwa as a Disseminator of Islamic Laws among Community of Malaysia
}

\author{
Wan Mohd Khairul Firdaus Wan Khairuldin \\ Faculty of Islamic Contemporary Studies, Universiti Sultan Zainal Abidin, Kampus Gong Badak, \\ Terengganu. \\ Email:wanfirdaus@unisza.edu.my
}

Wan Nur Izzati Wan Nor Anas

Academy of Islamic Studies, University of Malaya, Kuala Lumpur

Abdul Hanis Embong

Centre for Fundamental and Liberal Education, Universiti Malaysia Terengganu, Kuala Lumpur

\begin{abstract}
Fatwa is an instrument to answer many questions regarding laws among Muslim community. The delivery of fatwa is so crucial to the community as the production of fatwa is based on the problems of local community. The fatwa explanation in every problem is to resolve the confusion on religion happening in the community. Fatwa encompasses all aspects such as worship, interaction and in the field of science and technology. However, there are question arising which is what is the real function of fatwa in the framework of religious living in Malaysia? Therefore, to answer the question, this article owns two objectives. First, to explain the function of fatwa. Second, to explain the position of fatwa in the dissemination of Islamic laws to the Muslim community especially in Malaysia. To achieve these two objectives, therefore the documentation method was performed. The method was performed to obtain data related to fatwa from books. The collected data then were analysed through content analysis to discuss the function of fatwa as the disseminator of Islamic laws among the community. The findings of the study showed that fatwa is the disseminator of Islamic laws among Muslim community especially in Malaysia.
\end{abstract}

Keywords: Fatwa, Law, Disseminator, Website

INTRODUCTION

Every problem and confusion of the community on a certain matter related to Islamic laws will be explained through fatwa. Mufti is the most authorised person in the religion to explain and give 
INTERNATIONAL JOURNAL OF ACADEMIC RESEARCH IN BUSINESS AND SOCIAL SCIENCES Vol. 8, No. 11, Nov, 2018, E-ISSN: 2222-6990 C 2018 HRMARS

answer to the problem (Kassan \& Jamal, 2003; Khairuldin et al., 2016). The explanation to the problem related to Islamic laws is known as fatwa (Abdullah \& Rosele, 2016).

The word 'fatwa' derives from Arabic word which is futya. The scholars have posed different definition of fatwa. This can be viewed when Taha Abdullah al-dasuki defined fatwa as an explanation of a law which are explained by mujtahid fi al-mazhab or mujtahid mutlak. Meanwhile, according to Zaidan (1995), definition of fatwa is a problem which has a relationship with Islamic laws. Referring to al-Qasimi (1986), he said that fatwa is all the answers to problem in laws. Based on study by Kassan and Jamal (2003), there are two definitions by the scholars which can be summarised in defining fatwa. First, fatwa is the action of mufti in providing laws. Meanwhile, the second definition is that it is the name given to the laws. Thus, fatwa is an answer to the problem related to Islamic laws and the answer is given by the mufti. Nonetheless, should the question posed to the mufti not related to religious laws, so the answer given by the mufti is not considered as a fatwa.

As fatwa is an answer to the problem and confusion in Islamic laws, therefore it is viewed as having a function of disseminating Islamic laws among the community.

\section{METHODOLOGY}

Documentation method was exploited in this article to visualise a clear picture of fatwa as the propagator of Islamic laws among the community. Classical and contemporary documents were referred to collect data in obtaining as much information regarding fatwa.

The result of data collection was that they were analysed through content analysis method. Content analysis was used to scrutinise and explain the interpretations in the documents. Content analysis is research technique by making conclusion. The conclusion wasmade systematically and objectively through documented data. (Krippendorff, 2004 \& Rohana Yusof, 2004). The result of this analysis illustrates fatwa as the promulgator of Islamic laws among community.

\section{ANALYSIS}

Fatwa is the answer of mufti to the problem posed by mustafti. Fatwa plays an important role in delivering a certain Islamic law when the community is in the confusion on a certain matter related to Islam.

This kind of explanation for a certain law or fatwa did happen in the time of Rasulullah s.a.w. He provided explanation of law to the companions when there was any question from the companions. The law explanation was done by Rasulullah s.a.w. when there was no citation and evidence in alQuran and Hadis. Interaction of question and answer between the companions and Rasulullah s.a.w continued until the decease of Rasulullah s.a.w. (Khairuldin, 2016).

This tradition was resumed after his decease by the companions and followers of companions. According to Khalaf (1947), in the era of Abu Bakar caliphate, there were many answers provided to the problems which had no citation evidence in al-Quran and al-Sunnah. Meanwhile, during the 
caliphate of Umar al-Khattab, when a problem arised and had no proof in al-Quran and al-Sunnah, then he would refer to the answer of the law posed during the caliphate of Abu Bakar before setting up a meeting to get the answer for the problem (Galigo, 2002). In the era, there were many companions who produce fatwa and there were seven companions which were the most productive in the fatwa production. Among them were 'Aisyah umm al-Mu'minin, Umar al-Khattab, Ali bin Abi Talib, Ibn Abbas, Abd Allah ibn Mas'ud, Abd Allah ibn Umar al-Khattab and Zaid bin Thabit (Khairuldin, 2016).

When Islam spread, problems arised among the converts. Thus, beginning from this era, which was in the government of Khulafa' Umawiyyah, the fatwa production became very crucial even though at that time there was no specific, systematic organisation for fatwa production and no official position of mufti introduced.

Nevertheless, in the caliphate of Umar Ibn Abd al-Aziz, he founded the official position of mufti. And the mufti position has existed until nowadays (Khairuldin, 2010). According to al-'Umari (1986), in the meantime, there was Majma' al-Fiqh. Majma' al- Fiqh was founded and the purpose of its foundation was to organise discussioons between scholars to produce fatwa. This was an effort to solve the arising new problems. Therefore, with the existence of Majma' al-fiqh, the laws of Islam would be widespread among community.

In Malaysia, there are positions of mufti and organisation managing the fatwa which is the Fatwa Committee at the state level and the Fatwa Committee at the national level which is Committee of National Council for Islamic Affair of Malaysia (Rosele et al., 2013).

In Malaysia also, fatwa is produced by mufti together with Fatwa Committee. This means that mufti does not produce fatwa on his own. When a question is posed to the mufti and mufti answers without discussing with the Fatwa Committee first, the answer is not regarded as fatwa but as a personal opinion only. The opinion does not bind and cannot be made a law. On the other hand, if the question is discussed with the Fatwa Committee, the answer is considered as a fatwa. If the fatwa is gazetted, so the fatwa is regarded as a law and the Muslim community in Malaysia is bound to the fatwa (Nasohah, 2005).

\section{DISCUSSION}

Fatwa and Islamic law is the same subject as fatwa is an answer to the happening problem in the community regarding Islamic laws. There are various methods of fatwa dissemintation among Muslim community in Malaysia.

First, through the official website such as e-SMAF website and pamphlets distributed to the public. In addition, the fatwa is also disseminated through seminars organized by state fatwa institutions to the public to provide further clarification on the fatwa (Khairuldin et al., 2018). 
Second, through the gazette of fatwa. The gazette of fatwa means that the fatwa is published in the Warta (Gazette). When the fatwa has been gazetted, thus it binds the community in the state where the fatwa is gazetted. Therefore, fatwa and Islamic law itself which is gazetted, will be announced to the state community. This can be viewed in the 34(3) Act of Islamic Laws Management in Federal Territories.

When published in Warta, a fatwa should bind every residing Muslim in the Federal Territories as the teaching of his religion and it is his obligation of religion to obey and hold to the fatwa unless he is allowed by sharia laws to not obeying the fatwa in the matter of practice, belief and personal view.

Third, through Court. This can be seen when the court needs a referral to the mufti when a case occurs. Although the mufti's view is regarded as a personal opinion due to lack of initial discussion with the Fatwa Committee, but there was a case such as Dalip Kaur vs Police Officer of Bukit Mertajam ([1992]1ML1) which was requested by Civil Court to seek answer from the mufti and Fatwa Committee on the arising problem of sharia law in the case.

\section{CONCLUSION}

In conclusion, fatwa is one of the major forms of Islamic law in Malaysia. through a fatwa institution considered to be the most authoritative institution in the fatwa, the law decided by fatwa is disseminated through various mediums including official websites, seminars, pamphlets and books, court decisions and so on. This shows the importance of fatwa in the dissemination of Islamic law.

\section{ACKNOWLEDGEMENT}

This paper is founded on the research project of the Special Research Grant Scheme (SRGS)UniSZA/2017/SRGS/07. Special appreciation is owed RMIC Universiti Sultan Zainal Abidin (UniSZA) for sponsoring and supporting this research.

\section{REFERENCES}

Abdullah, L. \& Rosele, M.I. (2016). Isu Perbezaan Fatwa Di Malaysia: Satu Tinjauan dlm Seminar Fatwa Antarabangsa 2016. USIM.

Al-Dasuki, T. (1966). Usul al-fiqh, al-Qahirah : Matba`at Lujnat al-Bayan al-`Arabi

Al-Qasimi, J.D. (1986). Al-Fatwa fi al-Islam. Beirut: Dar al-Kutub al-'Ilmiyyah.

Galigo, S.B.A. (2002), al-ljtihad fi al-Fikr al-Islami, Kuala Lumpur : Fajar Ulung Sdn. Bhd.

Kasan H. \& Jamal, J. (2003). Fatwa dalam Perundangan Islam dan Fungsinya Menangani Keperlun Hukum Semasa Menurut Siasah al-Syariah, Jurnal Undang-Undang dan Masyarakat, 7 (2003): 89-111. 
Khairuldin, W. M. K. F. W., Embong, A. H., Anas, W. N. I. W. N., Mohd, H., \& Ismail, D. The Application Of Technology In The Dissemination Of Fatwas: A Study On Religious Institutions In Malaysia. International Journal of Civil Engineering and Technology, 9(7), 2018, pp. 1590-1596.

Khairuldin, W.M.K.F.W. (2016). Konsep Fatwa dalam Islam. Kuala Terengganu: Penerbit UniSZA.

Khairuldin, W.M.K.F.W., Ismail, D., Anas, W.N.I.W.N., Ibrahim, I., \& Fauzi, N. (2016). Freedom of Speeches by Mufti According to Islam: Implication to Fatwa in Malaysia. International Journal of Academic Research in Business and Social Sciences. 6 (12). Pp 141-151.

Khalaf, A.W. (1947), IIm Usul al-Fiqh wa Khulasah Tarikh al-Tasyri' al-Islami, Beirut : Jami'ah Fuad alAwwal.

Krippendorff, K. (2004). Content Analysis: An Introduction to Its Methodology. California: SAGE Publications Ltd.

Nasohah, Z. (2005). Undang-undang Penguatkuasaan Fatwa di Malaysia. ISLAMIYYAT, 27(1). pp 2544.

Rosele, M.I., Abdullah, L., Ismail, P. \& Ramli. M.A. (2013). Konflik Fatwa di Malaysia: Satu Kajian Awal. Jurnal Fiqh, vol. 10:31-56.

Yusof, R. (2004). Penyelidikan Sains Sosial. Kuala Lumpur: PTS Publications \& Distributors. 